\title{
Surface exposure ages imply multiple low-amplitude Pleistocene variations in East Antarctic Ice Sheet, Ricker Hills, Victoria Land
}

\author{
STEFAN STRASKY ${ }^{1 *}$, LUIGIA DI NICOLA ${ }^{2,3}$, CARLO BARONI ${ }^{4}$, MARIA CRISTINA SALVATORE ${ }^{5}$, \\ HEINRICH BAUR ${ }^{1}$, PETER W. KUBIK ${ }^{6}$, CHRISTIAN SCHLÜCHTER $^{3}$ and RAINER WIELER ${ }^{1}$ \\ ${ }^{1}$ Institute of Isotope Geochemistry and Mineral Resources, ETH Zurich, 8092 Zurich, Switzerland \\ ${ }^{2}$ Dipartimento di Scienze della Terra, Università degli Studi di Siena, 53100 Siena, Italy \\ ${ }^{3}$ Institute of Geological Sciences, University of Bern, 3012 Bern, Switzerland \\ ${ }^{4}$ Dipartimento di Scienze della Terra, Università di Pisa, e Istituto di Geoscienze e Georisorse CNR, 56126 Pisa, Italy \\ ${ }^{5}$ Dipartimento di Scienze della Terra, Università degli Studi di Roma 'La Sapienza', 00185 Rome, Italy \\ ${ }^{6}$ Paul Scherrer Institute, c/o Institute for Particle Physics, ETH Zurich, 8093 Zurich, Switzerland \\ *stefan.strasky@gmail.com
}

\begin{abstract}
One of the major issues in (palaeo-) climatology is the response of Antarctic ice sheets to global climate changes. Antarctic ice volume has varied in the past but the extent and timing of these fluctuations are not well known. In this study, we address the question of amplitude and timing of past Antarctic ice level changes by surface exposure dating using in situ produced cosmogenic nuclides $\left({ }^{10} \mathrm{Be}\right.$ and $\left.{ }^{21} \mathrm{Ne}\right)$. The study area lies in the Ricker Hills, a nunatak at the boundary of the East Antarctic Ice Sheet in southern Victoria Land. By determining exposure ages of erratic boulders from glacial drifts we directly date East Antarctic Ice Sheet variations. Erosion-corrected neon and beryllium exposure ages indicate that a major ice advance reaching elevations of about $500 \mathrm{~m}$ above present ice levels occurred between 1.125 and 1.375 million years before present. Subsequent ice fluctuations were of lesser extent but timing is difficult as all erratic boulders from related deposits show complex exposure histories. Sample-specific erosion rates were on the order of $20-45 \mathrm{~cm} \mathrm{Ma}^{-1}$ for a quartzite and $10-65 \mathrm{~cm} \mathrm{Ma}^{-1}$ for a sandstone boulder and imply that the modern cold, arid climate has persisted since at least the early Pleistocene.
\end{abstract}

Received 1 October 2007, accepted 21 April 2008

Key words: cosmogenic nuclides, erosion rates, glacial drifts, landscape evolution, surface exposure dating

\section{Introduction}

How sensitive are Antarctic ice sheets to global environmental change? When and to what extent did major Antarctic ice level variations occur in the past and will they recur in future? These are fundamental questions at the forefront of modern palaeoclimatology. As about $80 \%$ of the world's present freshwater is stored as Antarctic ice, melting of only a small fraction of ice would result in a global sea level rise, which is of prime concern to human society (Houghton et al. 2001). Considerable effort is therefore being spent to unravel the interactions between Antarctic ice volume variations and climate excursions in the past in order to predict future climate scenarios. The Scientific Committee on Antarctic Research (SCAR) is currently coordinating these efforts in an international research initiative, called Antarctic Climate Evolution (ACE).

It is generally believed that glaciation of East Antarctica started around the Eocene/Oligocene boundary, $\sim 34 \mathrm{Ma}$ ago (Barrett 1996), as atmospheric $\mathrm{CO}_{2}$ concentrations declined (DeConto \& Pollard 2003) and the opening of the Tasmanian Gateway and Drake Passage led to the continent's "thermal isolation" (Kennett 1977, Scher \& Martin 2006). Fluvial erosion sculpting dendritic valley systems ceased at the same time and temperate glaciers developed. Relict preglacial river valley systems that document the switch from fluvial to glacial landscape evolution - hence, the onset of ice growth - are observed in different areas of East Antarctica (e.g. Sugden \& Denton 2004, Baroni et al. 2005, Jamieson et al. 2005). From Oligocene to early Miocene times, oscillating warm-based ice existed for $\sim 15 \mathrm{Ma}$. Naish et al. (2001) investigated offshore sediment cores and observed 46 cycles of East Antarctic glacier advance and retreat for this time period. During the middle Miocene the thermal regime of East Antarctic ice bodies changed from warm- to cold-based and a hyperarid polar climate has been established ever since (Armienti \& Baroni 1999, Sugden \& Denton 2004, Lewis et al. 2007). This last phase in the evolution of the East Antarctic Ice Sheet (EAIS) is of particular interest, because amplitude and timing of EAIS volume changes over the past million years may serve as input parameters for modelling the future climate.

High resolution data of climate and environmental parameters can be derived from Antarctic ice cores (e.g. Petit et al. 1999, EPICA community members 2004). Their continuous records contribute significantly to the understanding of the past climate history (Wolff 2005). 


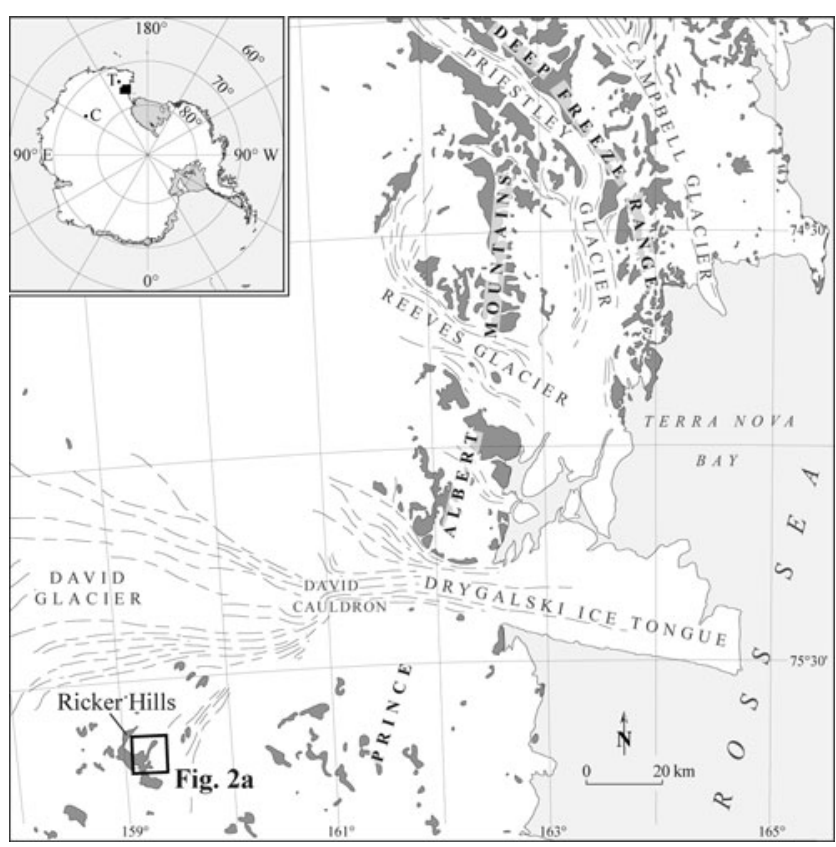

Fig. 1. Overview map of the David Glacier Basin, Victoria Land. The box in the lower left marks the location shown in Fig. 2a. $\mathrm{T}=$ Talos Dome, $\mathrm{C}=$ Dome $\mathrm{C}$.

However, the stratigraphy obtained from ice cores is limited to few drilling sites and at present only records the last $740 \mathrm{ka}$ (EPICA community members 2004). Furthermore, changes in ice elevation at the ice sheet margins cannot be inferred from ice cores. Therefore, detailed glacial geological and geomorphological mapping is required to reconstruct threedimensional palaeo-ice expansions. By dating surfaces of the mapped glacial features with in situ produced cosmogenic nuclides, information about timing of the ice fluctuations can be obtained. Glacial events ranging from Holocene to middle Miocene ages can be dated by choosing the appropriate nuclides (Gosse \& Phillips 2001). The combination of mapping and dating of the glacial record thus yields a powerful tool for palaeoclimate studies. Key sites for applying this methodological approach and investigating the glacial response to past climate change are the presently ice free areas of Antarctica. Glacial deposits resulting from several ice sheet expansions have been recorded in these locations (e.g. Denton et al. 1984) and preserved over millions of years (Schäfer et al. 1999). Recent work has shown the potential of cosmogenic nuclide analyses to reconstruct palaeoclimate and landscape evolution in Antarctica (e.g. Oberholzer et al. 2003, Sugden et al. 2005, Fink et al. 2006, Mackintosh et al. 2007). Nevertheless, most studies focus on coastal areas, where outlet glaciers play a central role in drift deposition, and/or they concentrate on the most recent deglaciation chronologies. We consider that the extent and timing of major Antarctic ice level changes that occurred earlier, i.e. prior to the late Pleistocene, need further investigation.
Here, we present surface exposure ages (using the cosmogenic nuclides ${ }^{10} \mathrm{Be}$ and ${ }^{21} \mathrm{Ne}$ ) from the Ricker Hills, a nunatak near the present-day margin of the EAIS in Victoria Land. By dating erratic boulders from late Pleistocene and pre-late Pleistocene glacial drifts in this area we directly date EAIS fluctuations. In addition to the glacial chronology, we determine amplitudes of the past ice level variations from detailed field surveys.

\section{Study site}

The Ricker Hills $\left(75^{\circ} 41^{\prime} \mathrm{S}, 159^{\circ} 10^{\prime} \mathrm{E}\right)$ are located in the south-western part of the nearly north-south striking Prince Albert Mountains, about $100 \mathrm{~km}$ inland from the Ross Sea coast, in southern Victoria Land (Fig. 1). They are an ice free area of approximately $70 \mathrm{~km}^{2}$ within the David Glacier system at the margin of the EAIS. Prevailing strong katabatic winds occur in the region and keep the nunatak ice free. The nunatak ranges in elevation from $900 \mathrm{~m}$ to $1830 \mathrm{~m}$ above sea level (a.s.l.).

\section{Geology of the area}

The geological basement in southern Victoria Land is made up of the late Cambrian Granite Harbour Igneous Complex that consists largely of coarse-grained granite and granodiorite and contains minor diorite and tonalite plutons and dykes (Capponi et al. 1999). During the Palaeozoic the basement was uplifted and eroded. This led to the formation of the Kukri Peneplain, which is thought to be pre-Devonian in age (Gunn \& Warren 1962). Above the peneplain the clastic sediments of the Beacon Supergroup rest unconformably on the basement. They predominantly consist of quartzsandstones and coarse arkosic sandstones (Ricker 1964). In the southernmost outcropping area of the Ricker Hills fossil plants indicate an early Triassic age for the Beacon sediments (Capponi et al. 1999). The highest stratigraphical unit in the area is represented by Jurassic extrusive Kirkpatrick basalts and intrusive Ferrar dolerites (Ricker 1964). Rocks of Ferrar dolerite constitute the main outcrops of the Ricker Hills (Ricker 1964). Sediments from the Beacon Supergroup and Kirkpatrick basalts are restricted to very rare isolated outcrops, while no occurrence of the basement is visible at the surface today (Capponi et al. 1999).

\section{Glaciological and geomorphological settings}

The east-west flowing David Glacier is the most important outlet glacier in Victoria Land. Its floating tongue, known as the Drygalski Ice Tongue, is about $20 \mathrm{~km}$ wide and extends over $100 \mathrm{~km}$ into the Ross Sea, thus it is a distinctive element of Victoria Land's coastline (Fig. 1). With an area of $214300 \mathrm{~km}^{2}$, David Glacier is one of the large glacier systems, draining Dome $\mathrm{C}$ with an annual outflow of $15.6 \pm 1 \mathrm{~km}^{3}$ (Rignot \& Thomas 2002). The drainage can 
a
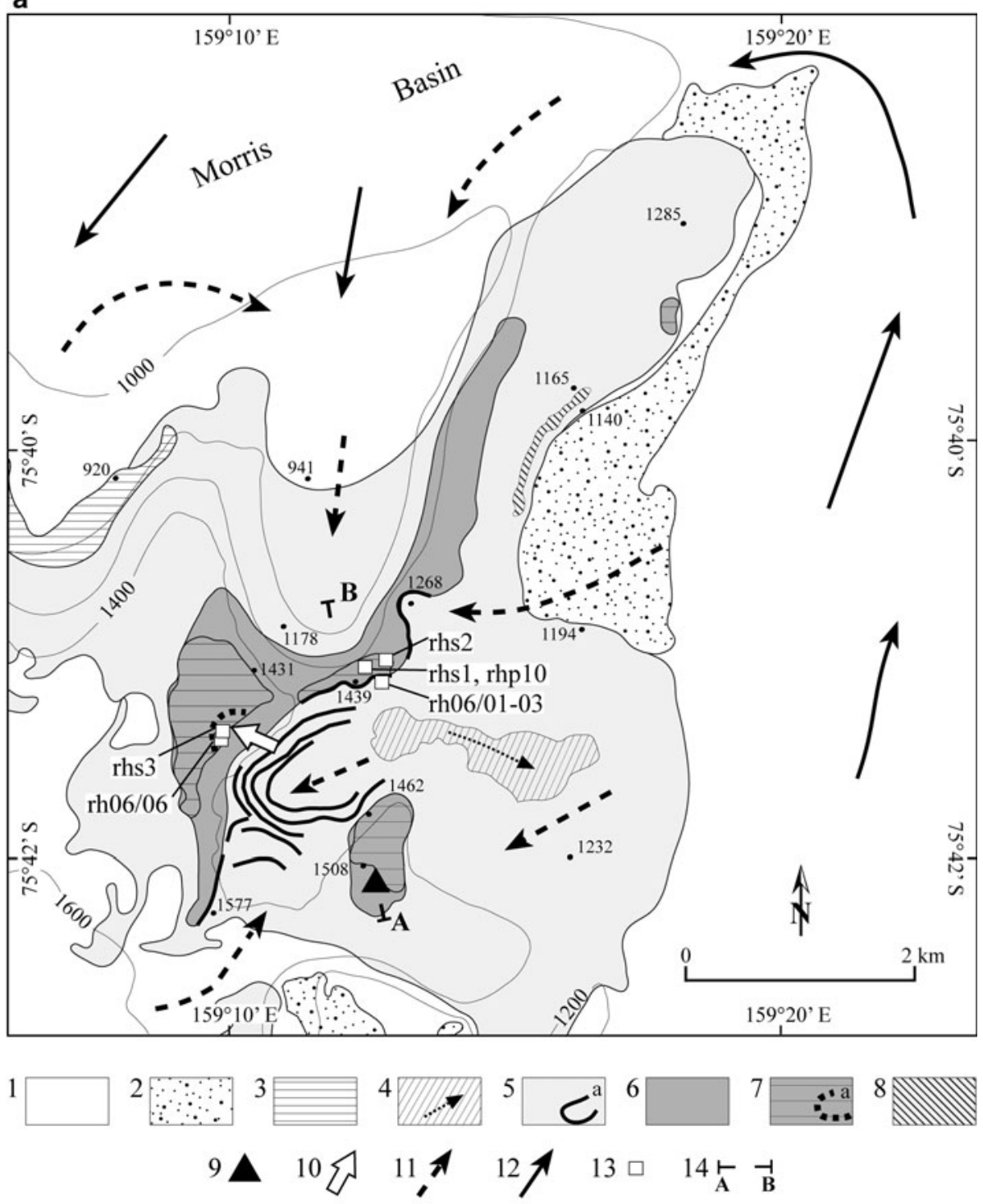

b

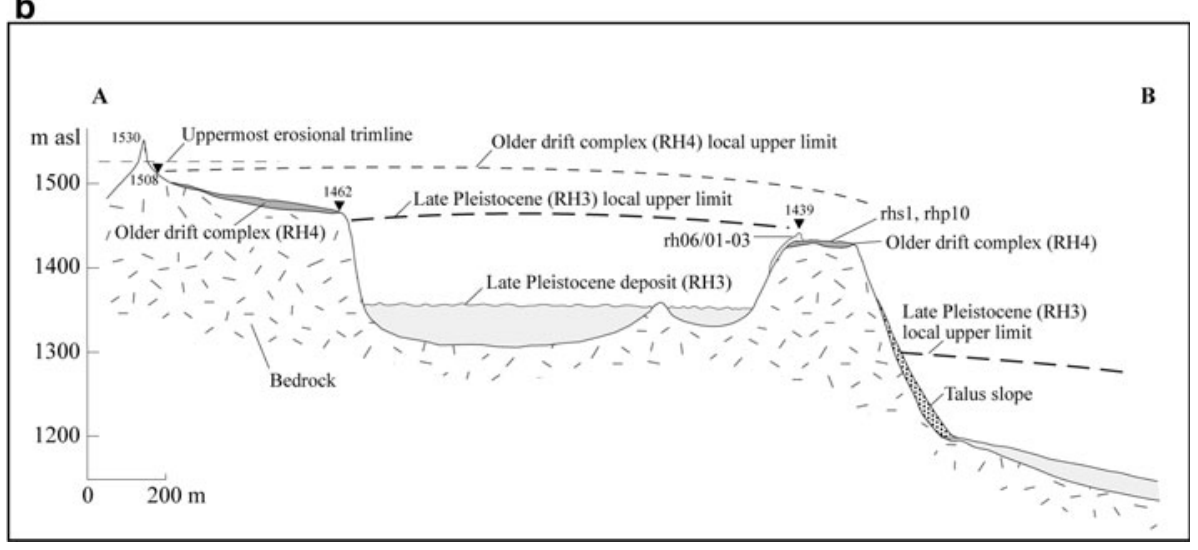

Fig. 2. a. Geomorphological map, and b. profile (see point 14 in a. for location) of the study area and sample positions. (1) Snow and glacier ice, (2) Supraglacial debris, (3) Holocene glacial deposit (RH1), (4) Remobilized late Pleistocene glacial deposit (Holocene, arrow $=$ flow direction), (5) Present ice free area overridden during late Pleistocene (RH3; $\mathrm{a}=$ moraine), (6) Late Pleistocene deglaciated area, (7) Older drift complex, early to middle Pleistocene (RH4; $\mathrm{a}=$ boulder alignment), (8) Ricker Hills Tillite, Oligocene (RH5), (9) Horn; (10) Older drift complex (RH4) ice flow direction, (11) Late Pleistocene ice flow direction, (12) Present ice flow direction, (13) Sample site, (14) Cross section. Contour lines from ADD (Antarctic Digital Database); dots with numbers: spot heights from GPS survey (elevation in metres). be divided into a smaller flow that slopes from Talos Dome to the Ross Sea and a main flow consisting of a network of tributaries, which drain the plateau area around Dome $\mathrm{C}$ and converge in a huge icefall (David Cauldron) north-west of the Ricker Hills. Ice flow around the Ricker Hills is generally SW-NE, but ice flow in an opposite direction occurs in depressions at the lee side of the nunatak (Fig. 2). Present-day ice levels in the nunatak's up- and downstream 

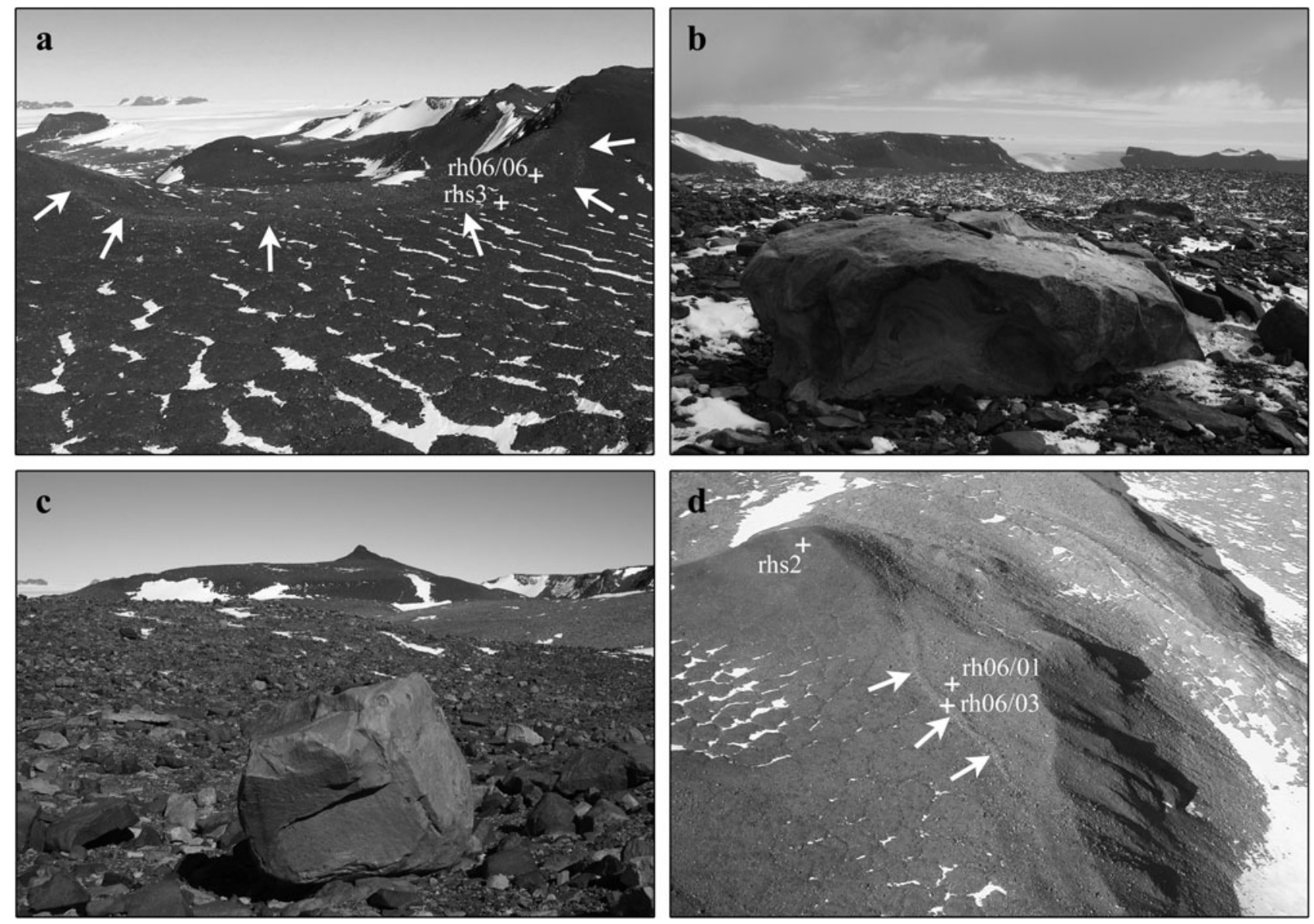

Fig. 3. a. Older drift lobe (RH4 site beta) with boulder alignment defining the upper limit of RH4; width of the lobe $\sim 450 \mathrm{~m}$. b. Sample rhs 3 from the RH4 drift lobe (note the hammer for scale). c. Sample rhs1 on the low-lying older drift (RH4 site alpha; note the hammer for scale). In the background is the horn mapped in Fig. 2a. d. Moraine in the middle of the picture delimiting the RH3 (right side) from the RH4 drift (left side). Horizontal width of the picture is $\sim 400 \mathrm{~m}$.

parts are $\sim 1750 \mathrm{~m}$ and $\sim 900 \mathrm{~m}$ a.s.1., respectively. Ice thicknesses vary considerably from site to site, reaching up to $1000 \mathrm{~m}$ in an adjacent sub-glacial valley east of the Ricker Hills (Delisle 1997).

Higher EAIS levels in the past have left substantial imprints on the surface morphology of the Ricker Hills. Areas with distinct glacial erosional and depositional features are widespread up to a certain altitude marked by a glacial trimline. Above the trimline a weakly developed alpine topography with deep cavernous weathering forms ridges and horns. This is evidence that glaciers never overrode the highest peaks after sculpturing the alpine topography. Geomorphological and glacial geological surveys of the Ricker Hills allowed at least five glacial drifts to be distinguished, hereafter informally named RH1 to RH5 (Baroni et al. 2008). RH1 and RH2 represent the youngest glacial drifts deposited during the Holocene and Late Glacial, respectively. They are characterized by ice-cored moraines and hummocky deposits around the current ice margin (RH1) and in the area of former ice lobes, below the late Pleistocene ice limit, where ice entered the nunatak depressions. Glacial sediments related to the late Pleistocene ice level limit (RH3) occur at higher elevations up to $\sim 300 \mathrm{~m}$ above the current ice stand, sometimes with welldefined moraine ridges (Figs $2 \& 3$ ). These deposits cover broad areas of the nunatak. They are to a large part still icecored and can be correlated to the "Terra Nova Drift" documented in the Terra Nova Bay region by Orombelli et al. (1991). Radiocarbon ages for the "Terra Nova Drift" in the Northern Foothills (Terra Nova Bay) bracket its age between 7.5 and $25 \mathrm{ka}$ before present (Orombelli et al. 1991). A fourth unit (RH4) indicates a Pleistocene drift deposit older than RH3. Yellowish-red or red staining of boulder surfaces are typical for RH4 deposits, and clearly differ from the grey colour of the RH3 drift. Scattered erratic boulders of RH4 occur up to the top of the hills, reaching elevations of about $500 \mathrm{~m}$ above the present ice level. Weathering degree and occurrence of erratic boulders within this drift correspond to Orombelli et al. (1991) observations for the "Older Drift". The oldest unit in the relative 
Table I. Neon and beryllium isotope data.

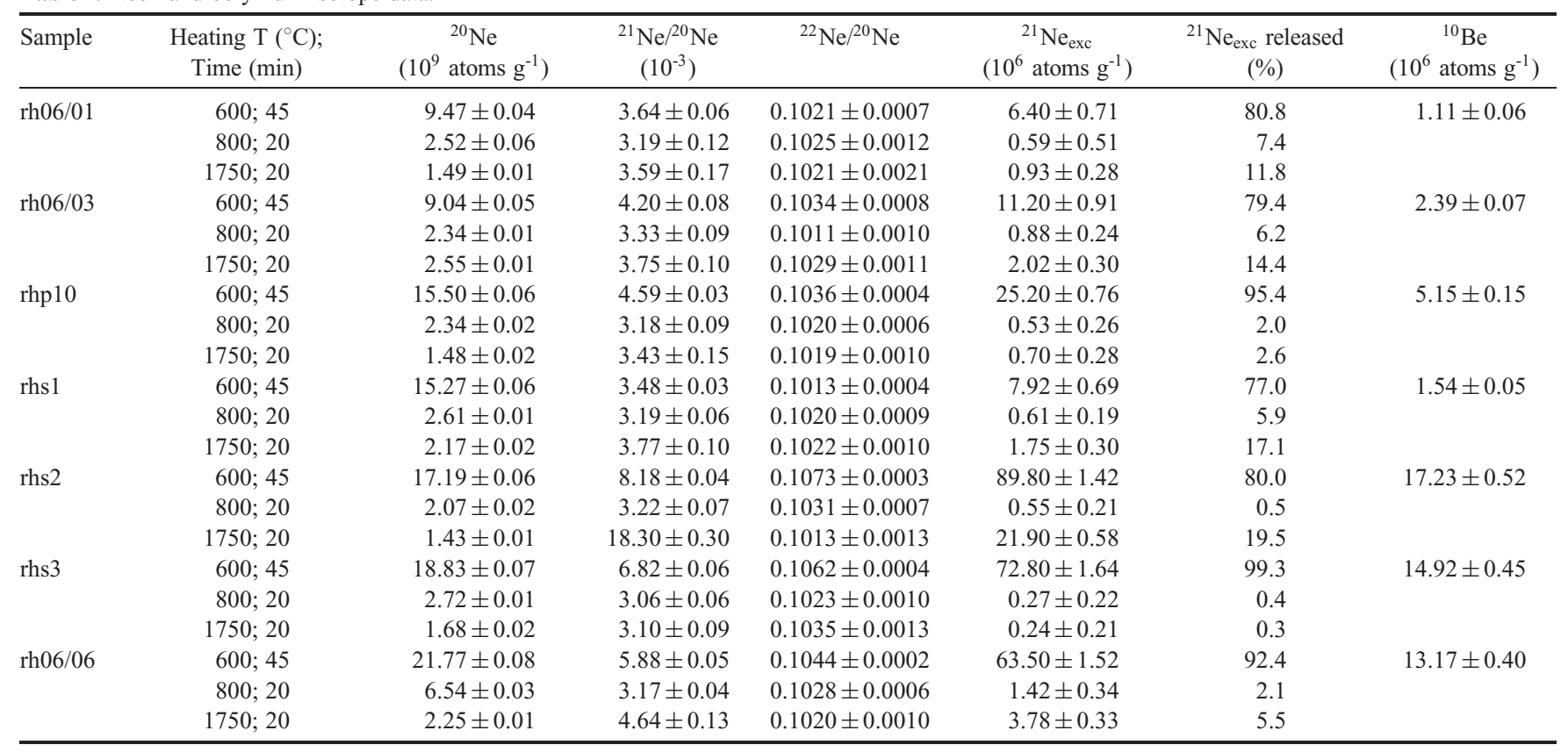

Errors are $1 \sigma$ and include uncertainties for the variability of chemical processing for the radionuclide, and statistical, sensitivity, and mass-discrimination errors for the noble gas measurements. Absolute errors of neon abundances are not included in the noble gas data, but are about $2 \%$ as determined with two independent air-calibrations. ${ }^{21} \mathrm{Ne}_{\mathrm{exc}}$ is the calculated ${ }^{21} \mathrm{Ne}$ excess over air.

stratigraphy of glacial deposits is the Ricker Hills Tillite (RH5). This is a semi-lithified diamicton that was deposited by a warm-based glacier most probably during Oligocene times (Baroni \& Fasano 2006, Baroni et al. 2008). Fig. 2 shows the different drifts and their spatial distribution in the investigated area (RH2 does not outcrop in this sector of the Ricker Hills) as well as the main geomorphological features.

\section{Sampling}

When sampling for surface exposure dating we focused on the nunatak's central part, where past ice lobes entered a depression from the north-west and distinct moraine ridges or drift boundaries are preserved. A suite of seven erratic boulders was sampled from three particular locations: RH3 moraines, and two different sites of RH4, a low-lying drift surface next to the RH3 moraines (site RH4 alpha), and a higher elevated drift surface (site RH4 beta). Sample positions are indicated on Fig. 2 and partly on Fig. 3, which shows in addition two sampled erratic boulders and gives insight into the local geomorphological situation of the area.

We collected rock material from two boulders (rh06/01 and rh06/03) from RH3 moraines that were separated only by a few metres and rest on the outermost moraine ridge delimiting the RH3 from the RH4 drift (Fig. 3d). Beyond the well-defined RH3 moraines, two samples (rhs1 and rhp10) were collected from a low-lying RH4 drift (site alpha) and another three (rhs2 \& 3 and rh06/06) from a higher elevated RH4 drift surface (site beta). The two highest samples (rhs3 and rh06/06) derive from erratics that belong to a boulder alignment, defining the upper limit of the RH4 drift (Fig. 3a).

All erratic boulders sampled for surface exposure age determination are Beacon sandstones, some of which have undergone slight metamorphic transformation. In the case of rhs2, the sandstone has changed completely into quartzite. In all cases, we sampled rock material from the erratic boulders' topmost $5 \mathrm{~cm}$ to minimize depth corrections. We performed careful field surveys in order to collect the most representative samples from a specific drift. For each boulder, its size, weathering degree, possible snow/ice cover and the likelihood of post-depositional movements were evaluated prior to sampling. Although the largest $\left(0.35\right.$ to $\left.2.15 \mathrm{~m}^{3}\right)$ and most stable boulders were sampled, post-depositional overturning can never be completely excluded, because drifts were probably still icecored for a long time after deposition (the RH3 drift is to a major part still ice-cored today).

\section{Surface exposure dating}

The quartz-rich sandstones we sampled are appropriate for cosmogenic nuclide analyses because quartz is relatively resistant to weathering and approved techniques allow the extraction of both cosmogenic neon (Niedermann et al. 

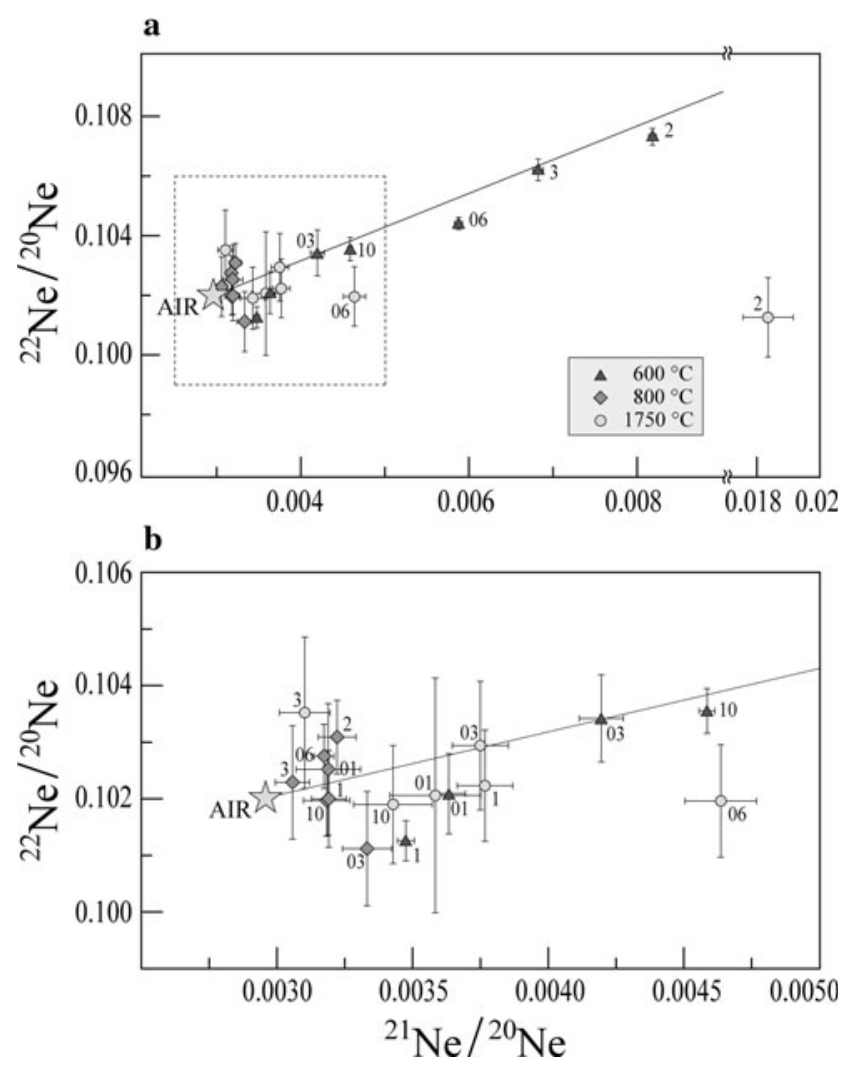

Fig. 4. Neon three-isotope diagrams. The line in the graphs is the atmospheric-cosmogenic mixing line for quartz, described by Niedermann et al. (1993). a. Data points from this study (error limits are $1 \sigma$ ). The dashed box shows the area of the diagram shown in b. b. An enlargement of the data that have low neon ratios. Sample abbreviations: $1-3$ represent samples rhs 1 to 3,10 represents sample rhp10, 01-06 represent samples rh06/01, 03 and 06 .

1993) and beryllium (e.g. Kohl \& Nishiizumi 1992). Cosmogenic nuclides, induced by cosmic ray spallation reactions within mineral lattices, accumulate in surface rocks in a predictable manner over time. Measuring the cosmogenic nuclide concentrations in minerals such as quartz thus allows determining how long a rock surface has been exposed to cosmic radiation (e.g. Lal 1991, Cerling \& Craig 1994). Coverage by, for example, glacial till, snow or ice can, however, reduce or completely stop cosmogenic nuclide production. Beneath more than about $5 \mathrm{~m}$ of ice, rock surfaces are essentially completely shielded from cosmic rays (Fabel \& Harbor 1999). When studying exposure ages of erratic boulders it is generally assumed that no cosmogenic nuclides are initially present prior to deposition and accumulation of cosmogenic nuclides starts with the melt-out ( $\sim$ deposition) of the boulder from the ice (i.e. a "simple exposure history"). This implies that the original surfaces of the erratic boulders were either completely shielded from incoming cosmic rays or glacial erosion exceeded $\sim 2 \mathrm{~m}$ (the maximum depth at which a

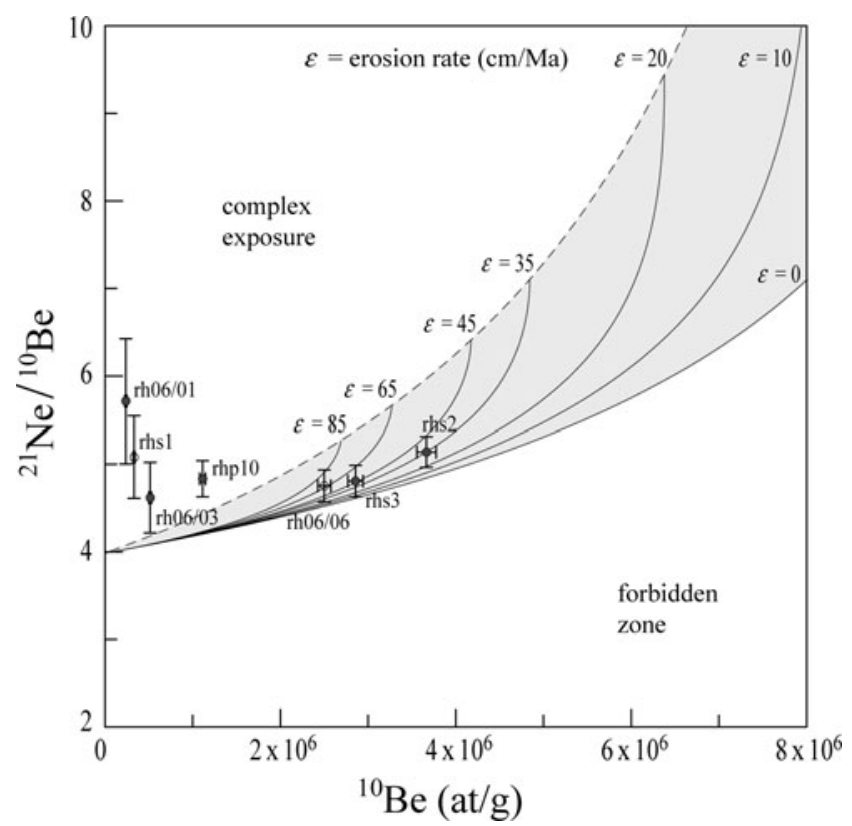

Fig. 5. Erosion island plot for all samples showing the effect of erosion on relative concentrations (normalized to sea level and high latitude) of ${ }^{21} \mathrm{Ne}$ and ${ }^{10} \mathrm{Be}$ for different erosion rates (solid lines). Dashed line connects steady-state erosion end points, the ratios where cosmogenic ${ }^{21} \mathrm{Ne}$ does not accumulate any more due to erosion. The grey zone is known as steady-state erosion island (Lal 1991). Samples with continuous exposure histories plot within the erosion island depending on erosion rates, whereas data plotting above indicate complex exposure. Open symbols mark the samples with possible non-cosmogenic ${ }^{21} \mathrm{Ne}$ contributions (rhs1, rh06/06) and therefore might plot too high in the diagram. The graph was produced using the calculation parameters indicated in the text and caption of Table II.

rock experiences a sizeable secondary cosmic ray particle flux) and removed all inherited nuclides from previous exposure times (Fabel \& Harbor 1999). However, in polar regions glacial erosion might not exceed this value and after retreat of a cold-based ice body, the overridden rock surfaces or erratic boulders may still contain some cosmogenic nuclides from an exposure period prior to the last ice advance (called a "complex exposure history"). To identify such a complex exposure history scenario and check whether a surface was intermittently shielded for a substantial period (= "burial period") a combined analysis of a stable and radioactive or two radioactive nuclides is necessary. During burial the ratio of the two nuclides changes (e.g. the ${ }^{21} \mathrm{Ne} /{ }^{10} \mathrm{Be}$ ratio increases), due to radioactive decay.

Analysis of two independent nuclides enables us to obtain two exposure ages for each sample. Such crossdating significantly increases our confidence in the reliability of an exposure age. Furthermore, in combination two or more different cosmogenic nuclide 
Table II. Calculated exposure ages.

\begin{tabular}{|c|c|c|c|c|c|c|c|c|c|}
\hline Sample & Drift & $\begin{array}{l}\text { Altitude } \\
\text { (m a.s.1.) }\end{array}$ & $\begin{array}{l}\text { Correction } \\
\text { factor }\end{array}$ & $\begin{array}{c}\text { Apparent } \\
{ }^{21} \mathrm{Ne} \text { age (ka) }\end{array}$ & $\begin{array}{c}\text { Apparent } \\
{ }^{10} \mathrm{Be} \text { age (ka) }\end{array}$ & $\begin{array}{l}{ }^{21} \mathrm{Ne} \text { age }(\mathrm{ka}) \\
\varepsilon=35 \mathrm{~cm} \mathrm{Ma}^{-1}\end{array}$ & $\begin{array}{c}{ }^{10} \mathrm{Be} \text { age }(\mathrm{ka}) \\
\varepsilon=35 \mathrm{~cm} \mathrm{Ma}^{-1}\end{array}$ & $\begin{array}{c}{ }^{21} \mathrm{Ne} \text { age }(\mathrm{ka}) \\
\varepsilon=45 \mathrm{~cm} \mathrm{Ma}^{-1}\end{array}$ & 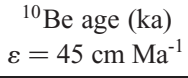 \\
\hline rh06/01 & RH3 & 1438 & 0.958 & $70 \pm 8$ & $49 \pm 3$ & $71 \pm 8$ & $50 \pm 3$ & $72 \pm 8$ & $50 \pm 3$ \\
\hline rh06/03 & RH3 & 1438 & 0.976 & $120 \pm 10$ & $106 \pm 3$ & $125 \pm 10$ & $110 \pm 3$ & $126 \pm 10$ & $111 \pm 3$ \\
\hline rhs 1 & RH4 $\alpha$ & 1438 & 0.962 & $86 \pm 7$ & $69 \pm 2$ & $88 \pm 8$ & $70 \pm 2$ & $89 \pm 8$ & $71 \pm 2$ \\
\hline rhs2 & RH4 $\beta$ & 1455 & 0.975 & $951 \pm 15$ & $900 \pm 27$ & $1396 \pm 22$ & $1423 \pm 43$ & $1686 \pm 27$ & $1892 \pm 57$ \\
\hline rhs3 & RH4 $\beta$ & 1589 & 0.962 & $703 \pm 16$ & $678 \pm 20$ & $908 \pm 20$ & $902 \pm 27$ & $1004 \pm 23$ & $1018 \pm 31$ \\
\hline
\end{tabular}

Exposure age calculations are based on sea level high latitude production rates $\mathrm{P}_{10}=5.1 \mathrm{at} / \mathrm{g} / \mathrm{yr}$ (Stone 2000), $\mathrm{P}_{21}=20.3$ at $/ \mathrm{g} / \mathrm{yr}(\mathrm{Niedermann} 2000)$ and the scaling model of Stone (2000). Correction factor includes geometric shielding and sample thickness (using $\Lambda=157 \mathrm{~g} \mathrm{~cm}^{-2}$ and $\rho=2.65 \mathrm{~g} \mathrm{~cm}^{-3}$ ). RH4 $\alpha$ and RH4 $\beta$ represent samples from the RH4 drift sites alpha and beta respectively. Apparent $=$ no erosion. Erosion-corrected ages for two reasonable erosion rates $\left(\varepsilon=35\right.$ and $45 \mathrm{~cm} \mathrm{Ma}^{-1}$, respectively) are given (see text and Fig. 5).

measurements from the same sample may yield valuable information about the sample-specific erosion rate and, as noted above, the exposure history (Lal 1991, Gosse \& Phillips 2001). In order to determine surface exposure ages from the Ricker Hills and to benefit from the potential of multiple nuclide analyses, we extracted and measured both cosmogenic ${ }^{21} \mathrm{Ne}$ and ${ }^{10} \mathrm{Be}$ from the erratic boulders we sampled.

\section{Sample preparation}

Rock samples were mainly processed at the Institute of Geological Sciences, University of Bern. In a first step the rocks were crushed and sieved into grain sizes between 0.25 and $0.4 \mathrm{~mm}$. In a second stage magnetic separation was applied to remove magnetic minerals before the samples were put into hydrochloric and hydrofluoric acids to chemically isolate quartz according to Kohl \& Nishiizumi (1992). A split of each purified quartz separate was then kept for noble gas analysis, while the rest underwent further chemical processing to extract ${ }^{10} \mathrm{Be}$ following standard procedures. The quartz splits for the ${ }^{21} \mathrm{Ne}$ measurements were further crushed to grain sizes $<0.1 \mathrm{~mm}$ and cleaned in an ultrasonic bath. The suspended finest fraction was subsequently decanted.

\section{Cosmogenic nuclide measurements}

Radionuclide analyses were carried out at the accelerator mass spectrometry facility of PSI/ETH Zurich. ${ }^{10} \mathrm{Be} /{ }^{9} \mathrm{Be}$ ratios were measured according to the method described by Synal et al. (1997) and used to calculate ${ }^{10} \mathrm{Be}$ concentrations. Cosmogenic ${ }^{21} \mathrm{Ne}$ was analysed in the noble gas laboratories of the Institute of Isotope Geochemistry and Mineral Resources at ETH Zurich. Samples of $40-60 \mathrm{mg}$ quartz were measured in a noncommercial ultra-high sensitivity mass spectrometer with a special ion source (see Baur 1999 for details). Noble gases were extracted from the samples through step-wise heating at 600,800 , and $1750^{\circ} \mathrm{C}$ to separate the cosmogenic from the non-cosmogenic (trapped and nucleogenic) neon components (Niedermann et al. 1993).

\section{Age calculation}

All exposure ages were calculated with CosmoCalc 1.0 (Vermeesch 2007), using altitude and latitude production rate scaling factors defined for the Antarctic region by Stone (2000), sea level high latitude production rates for ${ }^{21} \mathrm{Ne}$ and ${ }^{10} \mathrm{Be}$ of 20.3 and 5.1 atoms per gram quartz per year, respectively (Niedermann 2000, Stone 2000), an attenuation length $(\Lambda)$ of 157 gram per $\mathrm{cm}^{2}$ and default values for all other parameters. The ${ }^{21} \mathrm{Ne}$ concentrations used in the calculations derive from the neon excesses above air $\left({ }^{21} \mathrm{Ne}_{\text {exc }}\right)$ of the $600^{\circ} \mathrm{C}$ temperature steps under the assumption of entirely atmospheric ${ }^{20} \mathrm{Ne}$ concentrations. All relevant neon and beryllium isotope data for exposure age determination are shown in Table I and the neon three-isotope distribution is illustrated in Fig. 4. Details of the noble gas data are explained in the next section.

We corrected each date based on the slope of the sampled surface, topographic shielding by surrounding hills and mountains (Dunne et al. 1999), and for the sample thickness (Gosse \& Phillips 2001). A correction for shielding of the sampled erratic boulders by intermittent snow cover was not included in the calculations. Due to strong prevailing katabatic winds, we think it is unlikely that enough snow could accumulate to cover the erratic boulders (which have heights between 50 and $150 \mathrm{~cm}$ ). Exposure age corrections due to past geomagnetic intensity variations that affected cosmogenic nuclide production are not required for latitudes greater than about $60^{\circ}$ (e.g. Cerling \& Craig 1994). However, one effect that cannot be neglected is erosion. To account for erosion we determined sample-specific neon-beryllium erosion rates from an erosion island plot (Fig. 5) and adopted these values to calculate erosion-corrected ages. Sample-specific information and exposure ages calculated with a range of erosion rates are listed in Table II. 


\section{Results}

Surface exposure ages of all investigated erratic boulders are compiled in Table II. For each erratic boulder two independent exposure ages (neon and beryllium) are available. The apparent ${ }^{21} \mathrm{Ne}$ and ${ }^{10} \mathrm{Be}$ ages (assuming no erosion) range from $70 \pm 8$ to $951 \pm 15 \mathrm{ka}$ and from $49 \pm 3$ to $900 \pm 27 \mathrm{ka}$, respectively, and show broad agreement between each other.

Only the $600^{\circ} \mathrm{C}$ temperature steps were used to determine neon exposure ages, because most of the cosmogenic neon is released from quartz below this temperature and the higher temperature steps $\left(800,1750^{\circ} \mathrm{C}\right)$ usually contain noncosmogenic neon components (Niedermann et al. 1993). The cosmogenic origin of the $600^{\circ} \mathrm{C}$ steps is confirmed by the positions of the associated data points in the Neon three-isotope diagram (Fig. 4). With the exceptions of rhs1 \& 2 and rh06/06 they lie within errors on the atmospheric-cosmogenic mixing line. Within two-sigma confidence limits also the rhs2 point falls on the line, while data points of the other two samples still plot below the line. The ${ }^{21} \mathrm{Ne}_{\text {exc }}$ of the $600^{\circ} \mathrm{C}$ steps of rhs1 and rh06/06 might therefore not consist of cosmogenic neon only but contain additional non-atmospheric neon components, leading to an overestimation of the neon exposure ages. For this reason, ${ }^{21} \mathrm{Ne}$ dates for $\mathrm{rhs} 1$ and $\mathrm{rh06/06}$ are not considered in the conclusions.

Among the total dataset the oldest exposure ages (apparent ${ }^{10} \mathrm{Be}$ ages from $575 \pm 19$ to $900 \pm 27 \mathrm{ka}$ ) come from the high-elevated RH4 drift (site beta). Apparent ${ }^{10} \mathrm{Be}$ dates from the two other sampling locations (Fig. 2) are considerably younger and range from $69 \pm 2$ to $230 \pm 7 \mathrm{ka}$ for the lower-lying RH4 drift (site alpha) and from $49 \pm 3$ to $106 \pm 3 \mathrm{ka}$ in the case of the RH3 moraines. When taking erosion into account, exposure ages are shifted towards older dates. The older a sample and/or the higher the erosion rate, the larger the shift is (Table II).

\section{Discussion}

From the geomorphological position and weathering degree the older drift complex (RH4) is supposed to be older than late Pleistocene (Baroni et al. 2008). But when did ice retreat from these surfaces, and as a consequence, when did cosmogenic nuclide production start? As Table II reveals, the RH4 drift (apparent ${ }^{10} \mathrm{Be}$ exposure ages $69 \pm 2 \mathrm{ka}$ to $900 \pm 27 \mathrm{ka}$ ) generally predates the late Pleistocene, but no clear age cluster defines the timing of deglaciation. From the two investigated RH4 sites (alpha \& beta) the lower lying site alpha yields much younger apparent exposure ages $\left({ }^{10} \mathrm{Be}\right.$ ages $69 \pm 2 \mathrm{ka}$ and $\left.230 \pm 7 \mathrm{ka}\right)$ than the higher elevated site beta $\left({ }^{10} \mathrm{Be}\right.$ dates from $575 \pm 19 \mathrm{ka}$ to $900 \pm 27 \mathrm{ka}$ ), which points to an unequal drift evolution. Thus, the glacial situation seems to be more complex than expected from glacial geological and geomorphological surveys and requires careful data interpretation in order to reconstruct the glacial chronology of the Ricker Hills.

Although there is broad agreement between neon and beryllium apparent ages of the analysed erratic boulders, there are small but important ${ }^{21} \mathrm{Ne}$ and ${ }^{10} \mathrm{Be}$ age differences (all ${ }^{21} \mathrm{Ne}$ ages are older than ${ }^{10} \mathrm{Be}$ ages), which reveal valuable information about drift evolution. All erratic boulders from RH3 and low-lying RH4 (site alpha) drift surfaces have ${ }^{21} \mathrm{Ne}$ and ${ }^{10} \mathrm{Be}$ age differences that cannot be explained by continuous exposure because in Fig. 5 the ${ }^{21} \mathrm{Ne} /{ }^{10} \mathrm{Be}$ ratios plot above the erosion island in the complex exposure zone. The differences between the ${ }^{21} \mathrm{Ne}$ and ${ }^{10} \mathrm{Be}$ dates of these samples are most probably due to burial of the erratic boulders beneath non-erosive cold-based ice. Burial by ice plays an important role in Antarctica and limits the potential of cosmogenic nuclide dating under polar conditions (Sugden et al. 2005, Di Nicola et al. 2007). By contrast to the complex exposure histories of boulders from the low-lying surfaces, paired nuclide analyses of all erratic boulders from the high-elevated RH4 (site beta) surface indicate simple exposure histories (Fig. 5). This suggests that in the early Pleistocene ice levels reached the highest elevations in the Ricker Hills (up to $\sim 500 \mathrm{~m}$ above present-day ice levels) and subsequent EAIS variations were of lesser extent. During the middle Pleistocene the highest areas (including RH4 site beta) were ice free and only low elevations of RH4 (e.g. site alpha) close to RH3 deposits were intermittently ice covered.

\section{Effect of complex exposure}

The signature of complex exposure is observed throughout the low-elevated drifts RH4 site alpha and RH3. As stated earlier, one of the major processes leading to the evolution of complex glacial surfaces is intermittent burial by ice. With a very simple scenario - assuming no erosion and a simple exposure and a subsequent burial period - we can calculate a burial age from the nuclide concentrations. For rhp10 for example this would be in the order of $\sim 400 \mathrm{ka}$ and a total exposureburial history (burial age + apparent ${ }^{21} \mathrm{Ne}$ exposure age) of $\sim 665 \mathrm{ka}$ would result. Although this scenario is far from reality it gives an idea of how much burial time is needed to accommodate a rather small age difference obtained from two nuclides. Our results suggest that cold-based ice probably covered the low-lying RH4 surfaces of the Ricker Hills for a considerable time. Such a scenario may also apply to the evolution of the RH3 drift. A similar theoretical exposure-burial quantification for $\mathrm{rh} 06 / 01$ as for $\operatorname{rhp} 10$ reveals a total exposure-burial history of $\sim 1.1 \mathrm{Ma}$. Hence, the late Pleistocene ice advance probably entrained older erratic boulders and deposited them on RH3 moraines leading to deceptive old exposure ages.

On the contrary, overturning during reworking and/or rearrangements of erratic boulders after initial deposition due to melting processes in ice-cored drifts or periglacial activities 


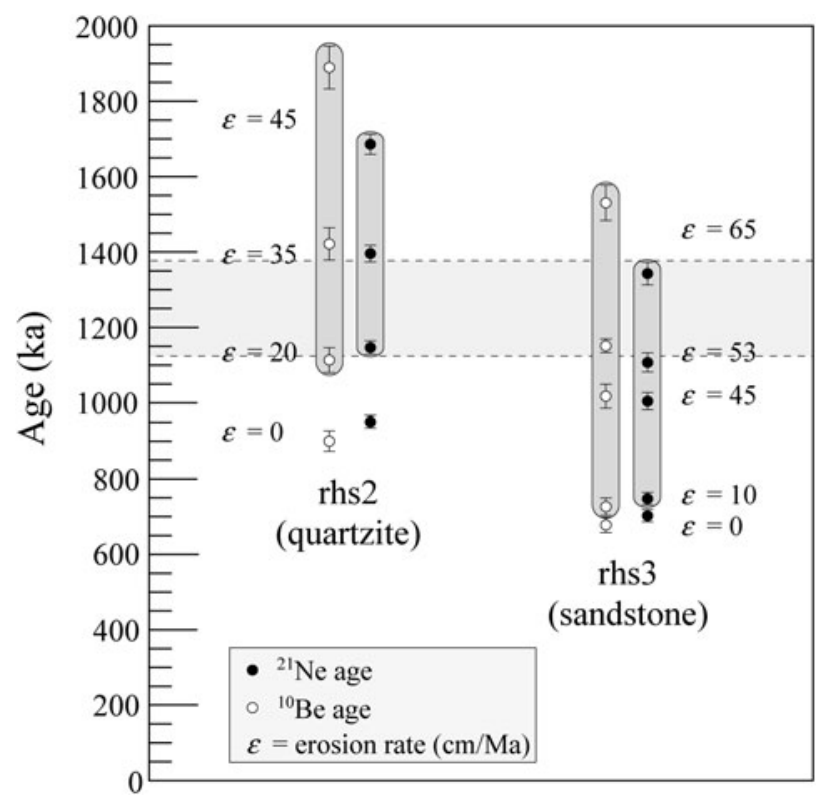

Fig. 6. Erosion-corrected exposure ages for the sample-specific range of erosion rates. The light grey horizontal band highlights the age overlap between 1125 and $1375 \mathrm{ka}$.

can result in falsely young ages and further add to the complexity of such deposits. Continuous post-depositional movements of $1 \mathrm{~mm}$ per year (seasonal changes summerwinter) would be large enough to overturn a boulder during its exposure period. Putkonen et al. (2008) measured regolith degradation in the McMurdo Dry Valleys of about $2 \mathrm{~m} \mathrm{Ma}^{-1}$ in a soil that is presently free of ice and visible moisture and was previously considered as a stable surface.

Burial by cold-based ice and post-depositional surface rearrangements lead to complex drift deposits that pose a challenging issue for surface exposure dating. Studying special geomorphological features like perched-boulders or pairs of erratics and glacially scoured bedrock as well as exposure histories of different surfaces (fully exposed and (partially) shielded) from the same boulder might help to address this issue in future. Furthermore, surface exposure dating with in situ produced cosmogenic ${ }^{14} \mathrm{C}$ could contribute to decipher the late Pleistocene glacial chronology, due to its short half-life compared to ${ }^{10} \mathrm{Be}$. Nevertheless, the identification of complex drifts demands multiple cosmogenic nuclide analyses since single nuclide exposure ages may result in misinterpretation of the glacial geological situation.

\section{Effect of erosion}

Erosion of the sampled erratic boulders during exposure times has continuously removed cosmogenic nuclides, hence lowered the apparent exposure ages. Correcting for erosion thus shifts the dates towards older exposure ages (Table II), which are more realistic as long as the adopted erosion rates reflect time-averaged local conditions. Erosion rates are generally very low in Antarctica due to the hyperarid polar climate; however, even extremely low erosion rates could significantly affect samples with apparent exposure ages in the order of several hundred thousand to million years (e.g. Schäfer et al. 1999). That erosion has to be considered in the study area is obvious from weathered boulders of RH4 deposits, which sometimes show cavernous weathering (Fig. 3b).

For the oldest two samples it was possible to determine erosion rates from a neon-beryllium erosion island plot (Fig. 5). The resulting erosion rates are $20-45 \mathrm{~cm} \mathrm{Ma}^{-1}$ for the quartzite rhs 2 and $10-65 \mathrm{~cm} \mathrm{Ma}^{-1}$ for the sandstone sample rhs3 (accounting for the errors in ${ }^{21} \mathrm{Ne}$ and ${ }^{10} \mathrm{Be}$ ), with best-fit values of 35 and $45 \mathrm{~cm} \mathrm{Ma}^{-1}$, respectively. These erosion rates are higher than previously reported for sandstone boulders (Ivy-Ochs et al. 1995, Schäfer et al. 1999) or granite bedrock (Oberholzer et al. 2003, Di Nicola et al. 2007), but are close to the values (17-41 $\mathrm{cm} \mathrm{Ma}^{-1}$ ) described by Oberholzer et al. (2008) for the nearby dolerite gargoyles and within the denudation range of sandstone bedrock indicated by Summerfield et al. (1999) for the McMurdo Dry Valleys area (13.3-60 $\left.\mathrm{cm} \mathrm{Ma}^{-1}\right)$. Adopting these erosion rates increases the exposure ages of the samples for the high-elevated RH4 drift (rhs3 \& 2) by roughly $45 \%$ to $\sim 1000$ and $\sim 1400 \mathrm{ka}$ (Table II).

The effect of erosion on calculated exposure ages is illustrated in Fig. 6 for both samples and the whole range of determined erosion rates. Figure 6 shows that erosioncorrected exposure ages of rhs 2 and rhs 3 overlap between 1125 and $1375 \mathrm{ka}$. This concordance leads us to believe that the high-elevated RH4 drift was deposited most likely during this time period. Accepting this implies erosion rates of $\sim 20-35 \mathrm{~cm} \mathrm{Ma}^{-1}$ for the quartzite and $\sim 53-65 \mathrm{~cm} \mathrm{Ma}^{-1}$ for the sandstone boulder (Fig. 6). These erosion rates differ only slightly from the graphically determined best-fit values (35 and $45 \mathrm{~cm} \mathrm{Ma}^{-1}$, Fig. 5) and seem to reflect samplespecific erosion rates most accurately for the given situation. Weathering degree and rock fragmentation of sampled boulders already suggested relatively lower erosion rates for the quartzite than for the sandstone sample in the field, which is confirmed with this finding.

Erosion has a less significant effect on exposure ages of younger samples. As a consequence, erosion-corrected cosmogenic nuclide ages for the low-lying RH4 drift (site alpha) and the RH3 surfaces generally vary less than ten percent from their apparent (no erosion) ages (Table II).

\section{Conclusions}

A deeply weathered glacial deposit (RH4), comparable to the "Older Drift" described in the Terra Nova Bay area by Orombelli et al. (1991), indicates a major EAIS advance in the Ricker Hills, Victoria Land, beyond the late Pleistocene 
drift limit. Apparent surface exposure ages based on cosmogenic ${ }^{21} \mathrm{Ne}$ and ${ }^{10} \mathrm{Be}$ for this older drift complex (RH4) confirms a pre-late Pleistocene age of the deposit, but at the same time suggests multiple episodes of glacial deposition. From our investigation we can divide the RH4 drift into two units, a lower (site alpha) and a higher elevated zone (site beta). The latter contains erratic boulders up to $\sim 500 \mathrm{~m}$ above present-day ice levels and its ages (apparent ${ }^{10} \mathrm{Be}$ ages from $575 \pm 19$ to $900 \pm 27 \mathrm{ka}$ ) give evidence for a major early Pleistocene EAIS advance. Erosion-corrected exposure ages from this surface, including a well-defined boulder alignment from the highest outcrops of this elevated drift zone, suggest that the major ice advance occurred between 1125 and $1375 \mathrm{ka}$ ago. Deposits from this glacial event seem to be only locally preserved, because subsequent ice advances possibly reworked other deposits of the same glacial phase. The range of erosion rates used to correct exposure ages were obtained from an erosion island diagram and are $10-65 \mathrm{~cm} \mathrm{Ma}^{-1}$ for a sandstone and $20-45 \mathrm{~cm} \mathrm{Ma}^{-1}$ for a quartzite.

The lower-lying RH4 drift unit (site alpha) represents a more complex deposit. Burial by cold-based ice seems to have played a major role in the evolution of the present surface. However, also other processes like reworking of older deposits and possibly post-depositional movements of the sub-surface could have affected the drift. Cosmogenic nuclide analyses of our samples do not allow determination of an accurate deposition age for this unit. But they indicate that the low-lying RH4 drift close to the RH3 drift was overridden by at least another Pleistocene ice advance, leaving the higher elevated surfaces unburied.

These results are important because the location of the Ricker Hills at the margin of the EAIS points to the conclusion that: 1) the nunatak has not been overridden by the EAIS during middle and late Pleistocene, 2) the position reached by the upper lobe (site beta) represents the maximum thickening of the EAIS during the entire Pleistocene, 3) glacial landforms in the Ricker Hills are older than the early Pleistocene and could date from the Pliocene or earlier, in accordance with Baroni et al. (2008), 4) the low erosion rates imply that the modern cold, arid climate has persisted since at least the early Pleistocene. This is in agreement with findings from northern Victoria Land (Oberholzer et al. 2003) and from sites further afield, such as the Shackleton Range (Fogwill et al. 2004) and the northern Prince Charles Mountains (Fink et al. 2006).

Cosmogenic nuclide measurements for the late Pleistocene deposit (RH3) in the Ricker Hills yield exposure ages that clearly pre-date the last glacial maximum $(\sim 21 \mathrm{ka})$ and indicate a complex drift evolution. One or more processes leading to complex deposits as noted above for the lowlying RH4 drift could also explain the data scatter of the samples from the RH3 moraine. Additional samples need to be investigated with special regard to complex exposure in order to reconstruct the evolution of the RH3 drift in the Ricker Hills.

Our study of glacial deposits in the Ricker Hills showed that at least two EAIS variations occurred during the early to middle Pleistocene, and that these fluctuations were of limited amplitudes of less than $\sim 500 \mathrm{~m}$. However, multiple cold-based ice advances can pose substantial difficulties for cosmogenic nuclide chronologies. Combined nuclide analyses are therefore a prerequisite for any meaningful surface exposure dating in polar areas and are needed to further complete the picture of how the EAIS reacted to Pleistocene climate change.

\section{Acknowledgements}

This research was funded by the Italian National Program on Antarctic Research (PNRA) and the Swiss National Science Foundation grant number: 200020-1052201/1. We gratefully acknowledge their support. Many thanks to F. Mancini for GPS survey of spot heights. We would like to thank the members of the XX and XXI Italian Antarctic Expeditions and the pilots of Helicopter New Zealand, who contributed greatly to successful sampling campaigns. Finally, we wish to thank David Marchant, Chris Fogwill and an anonymous reviewer for their helpful comments on an earlier version of this article.

\section{References}

Armienti, P. \& Baroni, C. 1999. Cenozoic climatic change in Antarctica recorded by volcanic activity and landscape evolution. Geology, 27, $617-620$.

BARONI, C. \& FAsAnO, F. 2006. Micromorphological evidence of warmbased glacier deposition from the Ricker Hills Tillite (Victoria Land, Antarctica). Quaternary Science Reviews, 25, 976-992.

Baroni, C., Fasano, F., Giorgetti, G., Salvatore, M.C. \& Ribecai, C. 2008. The Ricker Hills tillite provides evidence of Oligocene warm-based glaciation in Victoria Land, Antarctica. Global and Planetary Change, 60, 457-470.

Baroni, C., Noti, V., Ciccacci, S., Righini, G. \& Salvatore, M.C. 2005. Fluvial origin of the valley system in northern Victoria Land (Antarctica) from quantitative geomorphic analysis. Geological Society of America Bulletin, 117, 212-228.

Barrett, P.J. 1996. Antarctic palaeoenvironment through Cenozoic times - a review. Terra Antartica, 3, 103-119.

BAur, H. 1999. A noble-gas mass spectrometer compressor source with two orders of magnitude improvement in sensitivity. Eos Transactions $A G U$, 80, Abstract V22B-08.

Capponi, G., Crispini, L., Meccheri, M., Musumeci, G., Pertusati, P.C., Baroni, C., Delisle, G. \& Orsi, G. 1999. Antarctic geological 1:250,000 map series, Mount Joyce Quadrangle (Victoria Land). Siena: Museo Nazionale dell'Antartide, Sez. Scienze della Terra.

Cerling, T.E. \& Craig, H. 1994. Geomorphology and in-situ cosmogenic isotopes. Annual Reviews of Earth and Planetary Sciences, 22, 273-317.

DeConto, R.M. \& Pollard, D. 2003. Rapid Cenozoic glaciation of Antarctica induced by declining atmospheric $\mathrm{CO}_{2}$. Nature, 421, 245-249.

DelisLe, G. 1997. Sub-ice topography in selected areas of Victoria Land, Antarctica: implications for its glacial erosion history. Antarctic Research Series, 68, 127-135. 
Denton, G.H., Prentice, M.L., Kellogg, D.E. \& Kellogg, T.B. 1984. Late Tertiary history of the Antarctic Ice-Sheet: evidence from the Dry Valleys. Geology, 12, 263-267.

Di Nicola, L., Strasky, S., Schlüchter, C., Salvatore, M.C., Kubik, P.W., Ivy-Ochs, S., Wieler, R., AKçAR, N. \& Baroni, C. 2007. Complex exposure history of pre-LGM glacial drifts in Terra Nova Bay, Victoria Land, using a multiple cosmogenic nuclide approach. In COOPER, A.K., Raymond, C.R. \& ISAES Editorial Team, eds. Antarctica: a keystone in a changing world - online proceedings of the 10th ISAES X, USGS Open-File Report 2007-1047. Santa Barbara: US Geological Survey, 4 pp.

Dunne, J., Elmore, D. \& Muzikar, P. 1999. Scaling factors for the rates of production of cosmogenic nuclides for geometric shielding and attenuation at depth on sloped surfaces. Geomorphology, 27, 3-11.

EPICA COMMUNITY MEMBERS. 2004. Eight glacial cycles from an Antarctic ice core. Nature, 429, 623-628.

Fabel, D. \& Harbor, J. 1999. The use of in-situ produced cosmogenic radionuclides in glaciology and glacial geomorphology. Annals of Glaciology, 28, 103-110.

Fink, D., McKelvey, B., Hambrey, M.J., Fabel, D. \& Brown, R. 2006. Pleistocene deglaciation chronology of the Amery Oasis and Radok Lake, northern Prince Charles Mountains, Antarctica. Earth and Planetary Science Letters, 243, 229-243.

Fogwill, C.J., Bentley, M.J., Sugden, D.E., Kerr, A.R. \& KubiK, P.W. 2004. Cosmogenic nuclides ${ }^{10} \mathrm{Be}$ and ${ }^{26} \mathrm{Al}$ imply limited Antarctic Ice Sheet thickening and low erosion in the Shackleton Range for $>1 \mathrm{~m} . \mathrm{y}$. Geology, 32, 265-268.

Gosse, J.C. \& Phillips, F.M. 2001. Terrestrial in situ cosmogenic nuclides: theory and application. Quaternary Science Reviews, 20, 1475-1560.

GunN, B.M. \& Warren, G. 1962. Geology of Victoria Land between the Mawson and Mulock glaciers, Antarctica. New Zealand Geological Survey Bulletin, 71, 1-157.

Houghton, J.T., Ding, Y., Griggs, D.J., Noguer, M., van den Linden, P.J., DAI, X., Maskell, K. \& Johnson, C.A. 2001. Climate change 2001: the scientific basis. Cambridge: Cambridge University Press, 881 pp.

Ivy-Ochs, S., Schlüchter, C., Kubik, P.W., Dittrich-Hannen, B. \& Beer, J. 1995. Minimum ${ }^{10} \mathrm{Be}$ exposure ages of early Pliocene for the Table Mountain plateau and the Sirius Group at Mount Fleming, Dry Valleys, Antarctica. Geology, 23, 1007-1010.

Jamieson, S.S.R., Hulton, N.R.J., Sugden, D.E., Payne, A.J. \& Taylor, J. 2005. Cenozoic landscape evolution of the Lambert basin, East Antarctica: the relative role of rivers and ice sheets. Global and Planetary Change, 45, 35-49.

KennetT, J.P. 1977. Cenozoic evolution of Antarctic glaciation, the circumAntarctic Ocean, and their impact on global paleoceanography. Journal of Geophysical Research, 82, 3843-3860.

Kohl, C.P. \& Nishizumi, K. 1992. Chemical isolation of quartz for measurement of in-situ-produced cosmogenic nuclides. Geochimica et Cosmochimica Acta, 56, 3583-3587.

LAL, D. 1991. Cosmic ray labeling of erosion surfaces: in situ nuclide production rates and erosion models. Earth and Planetary Science Letters, 104, 424-439.

Lewis, A.R., Marchant, D.R., Ashworth, A.C., Hemming, S.R. \& Machlus, M.L. 2007. Major middle Miocene global climate change: evidence from East Antarctica and the Transantarctic Mountains. Geological Society of America Bulletin, 119, 1449-1461.

Mackintosh, A., White, D., Fink, D., Gore, D.B., Pickard, J. \& Fanning, P.C. 2007. Exposure ages from mountain dipsticks in Mac. Robertson Land, East Antarctica, indicate little change in ice-sheet thickness since the Last Glacial Maximum. Geology, 35, 551-554.

Naish, T.R., Woolfe, K.J., Barrett, P.J., Wilson, G.S., Atkins, C., Bohaty, S.M., Bücker, C.J., Claps, M., Davey, F.J., Dunbar, G.B., Dunn, A.G., Fielding, C.R., Florindo, F., Hannah, M.J., Harwood, D.M., Henrys, S.A., Krissek, L.A., Lavelle, M., van der Meer, J., McIntosh, W.C., Niessen, F., Passchier, S., Powell, R.D., Roberts, A.P., Sagnotti, L.,
Scherer, R.P., Strong, C.P., Talarico, F., Verosub, K.L., Villa, G., Watkins, D.K., Webb, P.N. \& WoniK, T. 2001. Orbitally induced oscillations in the East Antarctic ice sheet at the Oligocene/Miocene boundary. Nature, 413, 719-723.

Niedermann, S. 2000. The ${ }^{21}$ Ne production rate in quartz revisited. Earth and Planetary Science Letters, 183, 361-364.

Niedermann, S., Graf, T. \& Marti, K. 1993. Mass spectrometric identification of cosmic-ray-produced neon in terrestrial rocks with multiple neon components. Earth and Planetary Science Letters, 118, $65-73$.

Oberholzer, P., Baroni, C., Salvatore, M.C., Baur, H. \& Wieler, R. 2008. Dating late Cenozoic erosional surfaces in Victoria Land, Antarctica, with cosmogenic neon in pyroxenes. Antarctic Science, 20, 89-98.

Oberholzer, P., Baron, C., Schaefer, J.M., Orombelli, G., Ivy-Ochs, S., KubiK, P.W., BAur, H. \& Wieler, R. 2003. Limited Pliocene/Pleistocene glaciation in Deep Freeze Range, northern Victoria Land, Antarctica, derived from in situ cosmogenic nuclides. Antarctic Science, 15, 493-502.

Orombelli, G., Baroni, C. \& Denton, G.H. 1991. Late Cenozoic glacial history of the Terra Nova Bay region, northern Victoria Land, Antarctica. Geografia Fisica e Dinamica Quaternaria, 13, 139-163.

Petit, J.R., Jouzel, J., Raynaud, D., Barkov, N.I., Barnola, J.-M., Basile, I., Bender, M., Chappellaz, J., Davis, M., Delaygue, G., Delmotte, M., Kotlyakov, V.M., Legrand, M., Lipenkov, V.Y., Lorius, C., Pépin, L., Ritz, C., Saltzman, E. \& Stievenard, M. 1999. Climate and atmospheric history of the past 420,000 years from the Vostok ice core, Antarctica. Nature, 399, 429-436.

Putkonen, J., Balco, G. \& Morgan, D. 2008. Slow regolith degradation without creep determined by cosmogenic nuclide measurements in Arena Valley, Antarctica. Quaternary Research, 69, 242-249.

Ricker, J. 1964. Outline of the geology between Mawson and Priestley glaciers, Victoria Land. In ADIE, R.J., ed. Antarctic geology. Amsterdam: North Holland Publishing Company, 265-275.

Rignot, E. \& Thomas, R.H. 2002. Mass balance of polar ice sheets. Science, 297, 1502-1506.

Schäfer, J.M., Ivy-Ochs, S., Wieler, R., Leya, I., Baur, H., Denton, G.H. \& SCHLÜCHTER, C. 1999. Cosmogenic noble gas studies in the oldest landscape on earth: surface exposure ages of the Dry Valleys, Antarctica. Earth and Planetary Science Letters, 167, 215-226.

SCHER, H.D. \& MARTIN, E.E. 2006. Timing and climatic consequences of the opening of Drake Passage. Science, 312, 428-430.

Stone, J.O. 2000. Air pressure and cosmogenic isotope production. Journal of Geophysical Research, 105, 23753-23759.

Sugden, D. \& Denton, G. 2004. Cenozoic landscape evolution of the Convoy Range to Mackay Glacier area, Transantarctic Mountains: onshore to offshore synthesis. Geological Society of America Bulletin, 116, 840-857.

Sugden, D.E., Balco, G., Cowdery, S.G., Stone, J.O. \& Sass, L.C. 2005. Selective glacial erosion and weathering zones in the coastal mountains of Marie Byrd Land, Antarctica. Geomorphology, 67, $317-334$.

Summerfield, M.A., Stuart, F.M., Cockburn, H.A.P., Sugden, D.E., Denton, G.H., Dunai, T. \& Marchant, D.R. 1999. Long-term rates of denudation in the Dry Valleys, Transantarctic Mountains, southern Victoria Land, Antarctica based on in-situ-produced cosmogenic ${ }^{21} \mathrm{Ne}$. Geomorphology, 27, 113-129.

Synal, H.-A., Bonani, G., Döbeli, M., Ender, R.M., Gartenmann, P., Kubik, P.W., Schnabel, C. \& Suter, M. 1997. Status report of the PSI/ETH AMS facility. Nuclear Instruments and Methods in Physics Research, 123, 62-68.

Vermeesch, P. 2007. CosmoCalc: an Excel add-in for cosmogenic nuclide calculations. Geochemistry, Geophysics, Geosystems, 8, 10.1029/ 2006GC001530.

WoLfF, E.W. 2005. Understanding the past - climate history from Antarctica. Antarctic Science, 17, 487-495. 